\title{
THE EFFECT OF ACUTE ALKALOSIS ON RENAL METABOLISM OF AMMONIA IN CIRRHOTICS *
}

\author{
By EDWARD E. OWEN, MALCOLM P. TYOR AND DAVID GIORDANO $\dagger$ \\ (From the Departments of Medicine, Duke University Medical Center, and the Veterans Ad- \\ ministration Hospital, Durham, N. C.)
}

(Submitted for publication October 26, 1961; accepted February 1, 1962)

The kidney consistently releases ammonia into the renal venous circulation of normal subjects and patients with compensated liver disease (1-4). Under conditions of normal acid-base balance, the quantity released usually approximates the amount of ammonia excreted into urine $(3,4)$. From determinations of arteriovenous ammonia differences across various organs, it has become apparent that the release of ammonia into the renal vein represents a major source of the normal ammonia concentration in blood (5). Of possible clinical importance in this regard is the observation that under certain conditions patients with liver disease may increase their renal contribution of ammonia to the systemic circulation. The increase of blood ammonia concentration seen after the intravenous administration of acetazolamide and chlorothiazide can be adequately explained by concomitant increases in release of ammonia into renal vein $(3,6)$. It has been suggested that the alterations in renal ammonia release seen during carbonic anhydrase inhibition may result from a shift in the normal partition of ammonia between urine and renal venous blood because of a disproportionate increase in $\mathrm{pH}$ of urine as compared with that of peritubular fluid (3).

The present study deals with acute metabolic and respiratory alkalosis and was designed to obtain additional information on the role of the kidney in the regulation of the ammonia concentration in blood and to evaluate the effects of acute systemic alkalosis on total bidirectional renal release of ammonia.

\footnotetext{
* This study was supported in part by Grant A-3255 from the National Institutes of Health. Presented in part before the Southern Society for Clinical Research and the Southern Section of The American Federation of Societies for Clinical Research, January, 1961, New Orleans, La.

$\dagger$ Present address : Department of Medicine, University of Indiana School of Medicine, Indianapolis, Ind.
}

\section{METHODS}

Seventeen male patients with alcoholic nutritional cirrhosis and normal renal function were studied. None displayed clinical evidence of pre-coma, renal disease, or progressive hepatic deterioration; and all were recumbent and in the fasting state at the time of study. A constant intravenous infusion (Bowman pump) of $p$-aminohippurate $(\mathrm{PAH})$ was maintained throughout the study and was preceded by a priming dose of $\mathrm{PAH}$ calculated to provide plasma levels of approximately $2 \mathrm{mg}$ per $100 \mathrm{ml}$. Arterial and renal venous blood were obtained from a brachial artery and a catheterized renal vein. Renal venous blood was initially identified from catheter position and apparent arterialization; subsequent confirmation was obtained from $\mathrm{PAH}$ extraction. Each study was performed under conditions of mild water diuresis initiated and maintained by the intravenous infusion of 5 per cent glucose in water. Voided urines were collected under an oil-toluene mixture. When bladder emptying was unsatisfactory, urines were obtained from an indwelling Foley catheter. After two $15-$ to 20 -minute control periods, 8 subjects were given $400 \mathrm{mEq}$ of 7 per cent sodium lactate intravenously over a 30 - to 40 -minute period. The remaining 9 subjects were voluntarily hyperventilated for 20 to 25 minutes. Arteriorenal venous differences were obtained at the approximate midpoint of serial 10 - to 20-minute urine collections obtained before, during, and after each of these procedures. Blood and urine ammonia concentrations were measured by a modification of the micro-diffusion method of Brown, Duda, Korkes and Handler (7). Duplicate determinations agreed within \pm 7 per cent, and recovery of ammonia added to blood or urine consistently ranged between 94 and 105 per cent. PAH concentrations in blood and urine were determined by the method of Selkurt (8). The $\mathrm{pH}$ of whole blood and urine was measured with a Cambridge model $\mathrm{R} \mathrm{pH}$ meter equipped with an enclosed glass electrode. Measurements were made at room temperature, $25^{\circ}$ to $26^{\circ} \mathrm{C}$, and corrected to $37^{\circ} \mathrm{C}$ by Rosenthal's factor (9). The $\mathrm{CO}_{2}$ content was determined by the method of Van Slyke and Neill (10). The $\mathrm{pCO}_{2}$ was calculated from this value and the $\mathrm{pH}$ and hemoglobin concentration by the line chart of Van Slyke and Sendroy with a pK of 6.11 (11). Oxygen content and saturation were determined by the spectrophotometric method of Hickam and Frayser (12). Hematocrits were determined in Winthrobe tubes centrifuged at $3,000 \mathrm{rpm}$ for 30 minutes. 


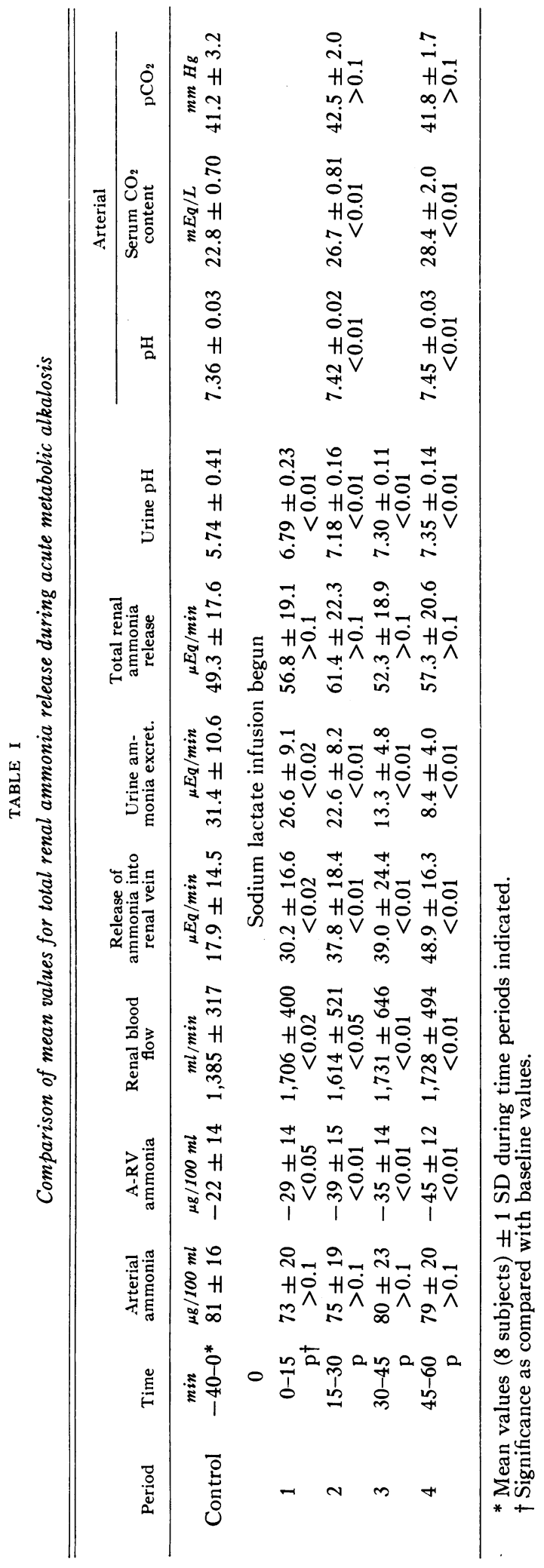

Renal plasma flow and blood flow were calculated according to standard $\mathrm{PAH}$ clearance procedures and corrected for $\mathrm{PAH}$ extraction. The release of ammonia into the renal venous circulation was calculated from the arteriorenal venous ammonia difference and renal blood flow. Total bidirectional release of ammonia was obtained by summing minute urine ammonia excretion and renal vein ammonia release. Details of these calculations have been previously published $(3,4)$.

\section{RESULTS}

Metabolic alkalosis induced by hypertonic sodium lactate. Mean values before and during four 15-minute periods after onset of a 7 per cent sodium lactate infusion are presented in Table $I$. Arterial $\mathrm{pH}$ increased at least 0.08 of a $\mathrm{pH}$ unit in each subject, and serum $\mathrm{CO}_{2}$ content increased at least $5.0 \mathrm{mEq}$ per L. Calculated $\mathrm{pCO}_{2}$ was not altered. The arterial ammonia concentration did not differ significantly from baseline values at any point during the 60-minute period of observation.

Control arteriorenal venous ammonia differences were consistently negative, indicating net release of ammonia into the renal venous circulation. A significant increase in the amount of ammonia released into the renal vein ( $12 \mu \mathrm{Eq}$ per minute; $\mathrm{p}<0.02$ ) was evident within 15 minutes, with a continued and progressive increase being observed during the remainder of the 1-hour study period. Although this increased release was largely due to changes in arteriorenal venous differences, renal blood flow also increased modestly during the sodium lactate infusion. The increase in ammonia released into the renal vein was closely approximated by a decrease in urine ammonia excretion during most clearance periods, so that total bidirectional renal release of ammonia was not significantly altered. Mean urine $\mathrm{pH}$ progressively increased throughout the 60 -minute study period (control mean, 5.74; 45- to 60-minute mean, 7.35). This peak in urine $\mathrm{pH}$ coincided with the maximal observed increase in release of ammonia into renal vein.

Renal arteriovenous oxygen differences and calculated renal oxygen consumptions were not altered during metabolic alkalosis. $\mathrm{PAH}$ extraction, likewise, was not significantly affected (mean control, 85.5 per cent; 60-minute mean, 82.1 per cent).

Respiratory alkalosis. Mean values before, during, and for two 20-minute periods after voluntary 
TABLE II

Comparison of mean values for total ammonia release during and after acute respiratory alkalosis

\begin{tabular}{|c|c|c|c|c|c|c|c|c|c|c|}
\hline \multirow[b]{2}{*}{ Period } & \multirow[b]{2}{*}{ Time } & \multirow{2}{*}{$\begin{array}{c}\text { Arterial } \\
\text { ammonia }\end{array}$} & \multirow{2}{*}{$\begin{array}{c}\text { A-RV } \\
\text { ammonia }\end{array}$} & \multirow{2}{*}{$\begin{array}{c}\text { Renal blood } \\
\text { flow }\end{array}$} & \multirow{2}{*}{$\begin{array}{c}\text { Release of } \\
\text { ammonia } \\
\text { into renal } \\
\text { vein }\end{array}$} & \multirow{2}{*}{$\begin{array}{l}\text { Urine } \\
\text { ammonia } \\
\text { excret. }\end{array}$} & \multirow{2}{*}{$\begin{array}{l}\text { Total } \\
\text { renal } \\
\text { ammonia } \\
\text { release }\end{array}$} & \multirow[b]{2}{*}{ Urine $\mathrm{pH}$} & \multicolumn{2}{|c|}{ Arterial } \\
\hline & & & & & & & & & $\overline{\mathrm{pH}}$ & $\mathrm{pCO}_{2}$ \\
\hline Control & $\begin{array}{c}\min \\
-40-0 *\end{array}$ & $\begin{array}{c}\mu g / 100 \mathrm{ml} \\
95 \pm 27\end{array}$ & $\begin{array}{c}\mu g / 100 m l \\
-43.4 \pm 54\end{array}$ & $\begin{array}{c}\mathrm{ml} / \mathrm{min} \\
1,194 \pm 506\end{array}$ & $\begin{array}{r}\mu E q / \min \\
29 \pm 36\end{array}$ & $\begin{array}{c}\mu E q / \min \\
39.8 \pm 19\end{array}$ & $\begin{array}{c}\mu E q / \min \\
68.8 \pm 41\end{array}$ & $5.96 \pm 0.70$ & $7.38 \pm 0.05$ & $\begin{array}{c}m m \mathrm{Hg} \\
39.4 \pm 7.5\end{array}$ \\
\hline \multicolumn{11}{|c|}{ Voluntary hyperventilation begun } \\
\hline 1 & $0-10$ & $105 \pm 31$ & $-44.9 \pm 47$ & $1,226 \pm 466$ & $30.8 \pm 31$ & $31.3 \pm 16$ & $60.9 \pm 36$ & $6.06 \pm 0.70$ & $7.55 \pm 0.05$ & $26.9 \pm 9.8$ \\
\hline 2 & $\underset{10-20}{\mathrm{p} \dagger}$ & $\begin{array}{c}<0.05 \\
116 \pm 31\end{array}$ & $\begin{array}{c}>0.1 \\
-28.8 \pm 53\end{array}$ & ${ }_{1,309}^{>0.1} \pm 515$ & $\begin{array}{c}>0.1 \\
19.1 \pm 39\end{array}$ & $\begin{array}{c}>0.1 \\
30.2 \pm 13\end{array}$ & $\stackrel{>0.1}{49.3 \pm 39}$ & $6.21^{>0.1} \pm 0.70$ & $\begin{array}{c}<0.01 \\
7.55 \pm 0.06\end{array}$ & $\begin{array}{c}<0.01 \\
24.3 \pm 5.3\end{array}$ \\
\hline & $\mathbf{p}$ & $<0.01$ & $>0.1$ & $>0.1$ & $>0.1$ & $<0.01$ & $<0.1$ & $<0.1$ & $<0.01$ & $<0.01$ \\
\hline \multicolumn{11}{|c|}{ 20-Minute hyperventilation ended } \\
\hline 3 & $20-40$ & $109 \pm 40$ & $-23.4 \pm 54$ & $1,192 \pm 690$ & $6.8 \pm 40.6$ & $20.9 \pm 12.8$ & $27.7 \pm 45$ & $6.26 \pm 0.70$ & $7.41 \pm 0.06$ & $35.1 \pm 8.2$ \\
\hline $4 \ddagger$ & $\begin{array}{r}p \\
40-60\end{array}$ & $\begin{array}{c}<0.01 \\
134 \pm 41\end{array}$ & $\begin{array}{c}<0.05 \\
-19+37\end{array}$ & $\begin{array}{c}>0.1 \\
1,367 \pm 673\end{array}$ & $\begin{array}{r}<0.05 \\
7.8 \pm 20\end{array}$ & $\begin{array}{c}<0.01 \\
26.9 \pm 17.3\end{array}$ & $\begin{array}{c}<0.01 \\
34.7 \pm 6\end{array}$ & $\begin{array}{c}<0.05 \\
5.99 \pm 0.41\end{array}$ & $\begin{array}{c}>0.1 \\
7.38 \pm 0.01\end{array}$ & $\begin{array}{c}<0.02 \\
40.8 \pm 3.9\end{array}$ \\
\hline & $\mathbf{p}$ & $<0.05$ & $>0.1$ & $>0.1$ & $<0.1$ & $<0.01$ & $<0.05$ & $>0.1$ & $>0.1$ & $>0.1$ \\
\hline
\end{tabular}

* Mean values $( \pm 1 \mathrm{SD})$ in 9 subjects during time period indicated.

t Significance as compared with resting values.

hyperventilation are presented in Table II. Hyperventilation resulted in more marked increases in arterial $\mathrm{pH}$ than did hypertonic sodium lactate infusion (mean control, 7.38; during hyperventilation, 7.55 ; 20 minutes after hyperventilation, 7.41 ; 40 minutes after hyperventilation, 7.38). In each experiment, calculated $\mathrm{pCO}_{2}$ decreased by at least $15 \mathrm{~mm} \mathrm{Hg}$ during hyperventilation. A modest increase in the arterial ammonia concentration was observed during hyperventilation and persisted throughout the remainder of the study. The release of ammonia into the renal vein was not significantly altered during the 20- to 25-minute period of maximal systemic alkalosis. However, a significant decrease in release was observed during the 20 -minute post-hyperventilation period, a time when arterial $\mathrm{pH}$ was not significantly different from control values. Urinary $\mathrm{pH}$ increased minimally during and after respiratory alkalosis (mean control $\mathrm{pH}, 5.96$ ); maximal increase occurred during the 20 minute post-hyperventilation period (mean $\mathrm{pH}, 6.26$ ). Ammonia excretion in urine showed a slight but consistent decrease. Total bidirectional renal release of ammonia decreased in 7 of 8 subjects during active hyperventilation. However, more dramatic and significant decreases were observed during the immediate post-hyperventilation periods. Renal blood flow, renal oxygen consumption, and $\mathrm{PAH}$ extraction were not significantly altered during or after voluntary hyperventilation.

\section{DISCUSSION}

It is apparent from the results that, in patients with liver disease, the effects of acute metabolic alkalosis and respiratory alkalosis on the arterial concentration of ammonia are distinctly different. As previously reported, acute hyperventilation results in significant increases in the concentration of ammonia in arterial blood. Increases are observed within 10 minutes of onset and occasionally persist for up to 1 hour after cessation of hyperventilation (13). As demonstrated in the present study, this increase cannot be explained by alterations in the quantity of ammonia added to renal venous blood. In addition, previous observations of arteriovenous ammonia differences indicate that the hyperammonemia of hyperventilation cannot be attributed to a decreased uptake of ammonia by the liver or extremity (13). Whether the increased increment of ammonia in blood, which occurs during and after acute respiratory alkalosis, arises from exercising respiratory muscles-as previously suggested (13) -or from other sites is at present unclear.

In contrast to respiratory alkalosis, acute metabolic alkalosis of similar degree and longer duration has no significant effect on the arterial ammonia concentration. Metabolic alkalosis consistently increases release of ammonia into renal vein to an extent similar to that seen after the intravenous administration of acetazolamide (3). 
Such an increased release might be expected to increase the ammonia concentration in blood under conditions of unchanged removal of ammonia by tissue. Since the arterial ammonia concentrations were not altered during the present study, presumptive evidence is provided for an increased ammonia uptake by tissue during metabolic alkalosis in man. Stabenau, Warren and Rall (14) have demonstrated an increased uptake of ammonia by brain and muscle during metabolic alkalosis in hyperammonemic rats; changes in tissue ammonia uptake during respiratory alkalosis, however, are minimized, presumably because of simultaneous equidirectional changes of $\mathrm{pH}$ in both cellular and surrounding fluid. Such observations are compatible with Jacobs' widely accepted hypothesis regarding the importance of $\mathrm{pH}$ gradients between cell and surrounding fluid in influencing the distribution of ammonia and other weak bases between cellular and extracellular fluid (15).

The renal response of patients with liver disease to acute metabolic and respiratory alkalosis is also distinctly different. Current concepts of renal metabolism and excretion of ammonia hold that ammonia is produced within the distal tubular cells and collecting ducts from the deamination and deamidation of certain amino acids. The ammonia thus formed may be excreted into urine, released into the peritubular fluid, or utilized within the tubular cells. Although extensive studies have been carried out dealing with urinary excretion of ammonia, information concerning the other fates of ammonia is meager. Most available evidence suggests that ammonia enters urine by a non-ionic diffusion process in accordance with the $\mathrm{pH}$ gradient between cell and tubular urine (16-18). In acid urines, ammonia excretion increases; and in alkaline urines, ammonia excretion decreases. Within the context of the nonionic diffusion theory, one might anticipate that release of ammonia into renal vein would be negligible in subjects with acid urine. The present observations and those previously reported have not confirmed such a relationship. Indeed, there seems to be no correlation between urine $\mathrm{pH}$ and release of ammonia into renal vein during steadystate situations in normal subjects and patients with liver disease $(4,5)$. This lack of conformity could be related to the maintenance of appropriate ammonia concentration gradients between renal tubular cells and peritubular fluid because of the rapid peritubular fluid flow as compared with tubular urine flow. Since the concentration of molecular ammonia in plasma is normally minimal, a rapid peritubular flow could prevent a concentration equilibruim of molecular ammonia between tubular cell and peritubular fluid. Such an arrangement might explain the findings of a constant release of ammonia into the renal veins under conditions of acid urine as well as during various degrees of systemic alkalosis.

The increase in ammonia release into renal vein and the decrease in urinary ammonia excretion in the present study during acute metabolic alkalosis are similar to results previously reported after intravenous acetazolamide and chlorothiazide. Although these observations may be explained on the basis of a passive shift in the partition of ammonia between urine and renal vein, they are not incompatible with a different process for ammonia excretion (i.e., active transport).

The response of the urinary $\mathrm{pH}$ to hyperventilation in this group of cirrhotic subjects differs from similar observations in normal subjects (19-20). In spite of a mean increase in arterial $\mathrm{pH}$ from 7.38 to 7.55 , urinary $\mathrm{pH}$ increased only from 5.82 to 6.17. Although a decrease in sodium delivery from distal tubules and a secondary decrease in the sodium-hydrogen exchange process could represent a possible mechanism in some of these patients, three of the subjects studied were clinically well compensated and had no evidence of sodium retention.

The pattern of bidirectional release of renal ammonia during and after active hyperventilation is somewhat at variance with results obtained with other methods of urine alkalinization. During hyperventilation, alterations consisted of a slight decrease in excretion of urinary ammonia, an insignificant change in release of ammonia into renal vein, and an over-all decrease in total renal release in seven of the eight subjects. Despite the increased $\mathrm{pH}$ of blood and, presumably, of peritubular fluid seen during hyperventilation, no consistent depression in the quantity of ammonia released into the renal vein was observed. During the post-hyperventilation period, a time when arterial $\mathrm{pH}$ had returned essentially to baseline values, release of ammonia into renal vein decreased in seven of the eight subjects, and total 
bidirectional ammonia release decreased consistently. These observations could be explained on the basis of either a decrease in endogenous production of renal ammonia or an increase in utilization of ammonia by renal tissue after acute respiratory alkalosis. Renal glutamine uptake was determined before, during, and after acute respiratory alkalosis in three subjects as an index of production of endogenous renal ammonia (21-22). Since no significant changes from control values were observed either during or after hyperventilation, it might be argued that increased utilization of ammonia by the kidney was primary. This line of reasoning gains some support from the suggestion that citrate synthesis and, secondarily, $\alpha$-ketoglutarate synthesis is increased with intracellular alkalosis (23). Since $\alpha$-ketoglutarate represents an important ammonia receptor, it is suggested that the decrease in excretion of urinary ammonia and release of ammonia into renal vein immediately after hyperventilation could be secondary to reductive amidation of $\alpha$-ketoglutarate by ammonia to form blutamate. These processes, as previously suggested by Lotspeich, would effectively decrease the availability of intracellular ammonia for transport and could account for the post-hyperventilation observation of a decrease in excretion of urinary ammonia and a decrease in the amount of ammonia added to renal venous blood (24).

\section{SUM MARY}

Total bidirectional release of renal ammonia was determined in eight cirrhotic subjects before and during acute metabolic alkalosis and in nine additional cirrhotics before, during, and after acute respiratory alkalosis induced by voluntary hyperventilation. Metabolic alkalosis was associated with rapid and significant increases in the quantity of ammonia added to renal venous blood and with reciprocal changes in excretion of urinary ammonia. The concentration of arterial ammonia remained unchanged.

Respiratory alkalosis resulted in an increase in ammonia concentration in blood, minimal increases in urinary $\mathrm{pH}$, and an insignificant change in total bidirectional release of renal ammonia. During the immediate post-hyperventilation period, total bidirectional release decreased consistently without an associated decrease in renal uptake of glutamine.

These observations indicate a lack of effect of physiological degrees of systemic alkalosis on the release of ammonia into the renal venous circulation. The decrease in total bidirectional release of renal ammonia after acute respiratory alkalosis seems best explained on the basis of an increase in utilization of renal ammonia.

\section{REFERENCES}

1. McDermott, W. V., Jr., Adams, R. D., and Riddell, A. G. Ammonia metabolism in man. Ann. Surg. 1954, 140, 539.

2. White, L. P., Phear, E. A., Summerskill, W. H. J., and Sherlock, S. Ammonium tolerance in liver disease: observations based on catheterization of the hepatic veins. J. clin. Invest. 1955, 34, 158.

3. Owen, E. E., Tyor, M. P., Flanagan, J. F., and Berry, N. J. The kidney as a source of blood ammonia in patients with liver disease: The effect of acetozalamide. J. clin. Invest. 1960, 39, 288.

4. Owen, E. E., Johnson, J. H., and Tyor, M. P. The effect of induced hyperammonemia on renal ammonia metabolism. J. clin. Invest. 1961, 40, 215.

5. Tyor, M. P., Owen, E. E., Berry, J. N., and Flanagan, J. F. The relative role of extremity, liver, and kidney as ammonia receivers and donors in patients with liver disease. Gastroenterology 1960, 39,420 .

6. Owen, E. E., Flanagan, J. F., and Tyor, M. P. Kidney as a source of blood ammonia : Effect of chlorothiazide. Proc. Soc. exp. Med. (N. Y.) 1959, 102, 696.

7. Brown, R. H., Duda, G. D., Korkes, L., and Handler, $P$. Colorimetric micromethod for the determination of ammonia: The ammonia content of rat tissues and human plasma. Arch. Biochem. 1957, 66, 301.

8. Selkurt, E. C. Measurement of renal blood flow. Meth. med. Res. 1949, 1, 191.

9. Rosenthal, T. B. The effect of temperature on the $\mathrm{pH}$ of blood and plasma in vitro. J. biol. Chem. 1948, 173, 25.

10. Van Slyke, D. D., and Neill, J. M. The determination of gases in blood and other solutions by vacuum extraction and manometric measurements. I. J. biol. Chem. 1924, 61, 523.

11. Van Slyke, D. D., and Sendroy, J., Jr. Studies of gas and electrolyte equilibria in blood. XV. Line charts for graphic calculations by the HendersonHasselbalch equation, and for calculating plasma carbon dioxide from whole blood content. J. biol. Chem. 1949, 79, 781.

12. Hickam, J. F., and Frayser, R. Spectrophotometric determination of blood oxygen. J. biol. Chem. 1949, 180, 457. 
13. Berry, J. N., Owen, E. E., Flanagan, J. F., and Tyor, M. P. The effect of acute hyperventilation on the blood ammonia concentration of patients with liver disease. J. Lab. clin. Med. 1960, 55, 849.

14. Stabenau, J. R., Warren, K. S., and Rall, D. P. The role of $\mathrm{pH}$ gradient in the distribution of ammonia between blood and cerebrospinal fluid, brain and muscle. J. clin. Invest. 1959, 38, 373.

15. Jacobs, M. H. Some aspects of cell permeability to weak electrolytes. Cold Spr. Harb. Symp. quant. Biol. 1940, 8, 30.

16. Pitts, R. F. Renal excretion of acid. Fed. Proc. 1948, 7, 418.

17. Leonard, E., and Orloff, J. Regulation of ammonia excretion in the rat. Amer. J. Physiol. 1955, 182, 131.

18. Orloff, J., and Berliner, R. W. The mechanism of the excretion of ammonia in the dog. J. clin. Invest. $1956,35,223$.
19. Stanbury, S. W., and Thomson, A. E. The renal response to respiratory alkalosis. Clin. Sci. 1952, $11,357$.

20. Barker, E. S., Singer, R. B., Elkinton, J. R., and Clark, J. K. The renal response in man to acute experimental respiratory alkalosis and acidosis. J. clin. Invest. 1957, 36, 515.

21. Van Slyke, D. D., Phillips, R. A., Hamilton, P. B., Archibald, R. M., Futcher, P. H., and Hiller, A. Glutamine as source material of urinary ammonia. J. biol. Chem. 1943, 150, 481.

22. Owen, E. E., and Tyor, M. P. Glutamine as a source of renal ammonia in normals and cirrhotics. Clin. Res. 1961, 9, 207.

23. Stern, J. R., Ochoa, S., and Lynen, F. Enzymatic synthesis of citric acid. V. Reaction of acetyl coenzyme A. J. biol. Chem. 1952, 198, 313.

24. Lotspeich, W. D. Metabolic Aspects of Renal Function. Springfield, Ill., Thomas, 1959. 